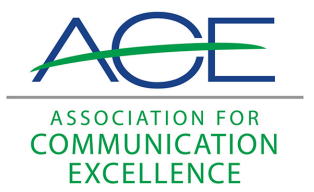

Journal of Applied Communications

\title{
Farm Broadcasting--The First Sixty Years; Agri Marketing; "Public Service Utilization by Texas Radio Stations"; "Enjoyment and information Gain in Science Articles"; "Choose the right color for your Learning Style."; Instant Speaking Course
}

Richard Lee

Delmar Hatesohl

Randy Weckman

See next page for additional authors

Follow this and additional works at: https://newprairiepress.org/jac

(c) (1)(2)

This work is licensed under a Creative Commons Attribution-Noncommercial-Share Alike 4.0 License.

Recommended Citation

Lee, Richard; Hatesohl, Delmar; Weckman, Randy; Sanders, Annette; and Marks, Joe (1981) "Farm Broadcasting--The First Sixty Years; Agri Marketing; "Public Service Utilization by Texas Radio Stations"; "Enjoyment and information Gain in Science Articles"; "Choose the right color for your Learning Style."; Instant Speaking Course," Journal of Applied Communications: Vol. 64: Iss. 2. https://doi.org/10.4148/ 1051-0834.1787

This Review is brought to you for free and open access by New Prairie Press. It has been accepted for inclusion in Journal of Applied Communications by an authorized administrator of New Prairie Press. For more information, please contact cads@k-state.edu. 
Farm Broadcasting-The First Sixty Years; Agri Marketing; "Public Service Utilization by Texas Radio Stations"; "Enjoyment and information Gain in Science Articles"; "Choose the right color for your Learning Style."; Instant Speaking Course

\begin{abstract}
Reviews of Farm Broadcasting--The First Sixty Years, by John C. Baker ; Agri Marketing; "Public Service Utilization by Texas Radio Stations," by W. Bryant Boutwell; "Enjoyment and information Gain in Science Articles," by Alan Hunsaker; "Choose the Right Color for Your Learning Style," by Esther R. Sinofsky and Frederick G. Knirk; Instant Speaking Course, by B. Lauren Lillis.
\end{abstract}

\title{
Authors
}

Richard Lee, Delmar Hatesohl, Randy Weckman, Annette Sanders, and Joe Marks 


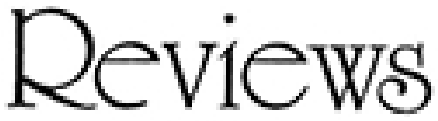

Includes revlews of articles and books on practical communicstions and on communications training. Sond reviews of 1 or 2 typed pages to Jim Shanor, 1-98 Agriculture Bullding. Univeralty of Missourh-Columbla 65211.

Farm Broadcasting-The First Sixty Years. John C. Baker, Ames, lowa: The lowa State University Press, 1981.

It's so commonplace that we may tend to think the word radio has been with us forever. Not so, says John C. Baker, author of a new book Farm BroadcastingThe First Sixty Years.

Radio was coined in 1911 by J. Howard Dellinger, a U.S. Bureau of Standards physicist. Broadcasting has a long history of agricultural usage but "radio broadcasting" came into being in 1912 when the U.S. Navy began to use the term to indicate messages intended for all ships or for anyone listening as opposed to messages intended for only one ship.

Baker also has some other interesting bits of information in his introductory chapters. For example, the first regularly scheduled weather forecast on voice radio was broadcast Jan. 3,1921 , on station 9XM (now WHA) by the University of Wisconsin.

But these tidbits aren't what make Farm Broadcasting a worthwhile book. We all know-even die-hard, print-oriented types-that radio has proven itself to be a valuable channel to get information to farm people.

Baker's book describes the role radio-and later television-has played in channeling information to farm people. Anyone interested in farm broadcasting or in the dissemination of information should have a copy of this valuable reference.

The author had a long career as a farm broadcaster. Baker graduated from Purdue University in 1930 and did 
extension radio work for Purdue for two years and the University of Massachusetts for four.

Then followed two periods each on WLS, Chicago, and the U.S. Department of Agriculture where he took part in the "National Farm and Home Hour" on NBC and "The American Farmer" on ABC. During the 1950s and 60 s Baker concluded his career as an information officer for the USDA and the Bureau of the Census.

Baker's career provided him with an insight into his subject that not many, if any, other farm broadcasters might have.

Having been a part of the NBC (remember the red and blue networks) National Farm and Home Hour for so many years, Baker provides a good insight into that venerable daily program from its beginning Oct. 2,1928 , to its end June 19,1944 , and its resurrection as a weekly program in 1945 to its eventual demise in 1960 .

These descriptive paragraphs contain names known to many ACE members, particularly the older variety (Ralph Reeder's SOB group). Included are Everett Mitchell (it's a beeyoutiful day in Chicago); Wallace Kadderly (ACE Rueben Brigham award winner in 1963); Ken Gapen; Milton Eisenhower; Secretaries of Agriculture Arthur M. Hyde, Henry A. Wallace, and Claude M. Wickard; and many others.

The first seven chapters in Farm Broadcasting trace the development of farm broadcasting at the national level and in the USDA. The next 48 chapters-sorry Alaska and Delaware-are devoted to accounts of the development of farm broadcasting in each state.

In the state-by-state accounting Baker typically describes the roles of the Cooperative Extension Service and farm organizations (particularly the Farm Bureau) in the development of farm broadcasting. He also mentions the radio stations that have a history in farm broadcasting and noted farm broadcasters.

The state-by-state accounting is followed by a chapter on the National Association of Farm Broadcasters. Baker has been a NAFB member since its first national meeting in 1945.

Only an author willing to devote months and years to a project could have gathered the material that is inhttps://newprairiepress.org/jac/v0164//ss2//6te chapters. Baker is to be com- 
Lee et al.: Farm Broadcasting--The First Sixty Y ears; A gri M arketing; "Public mended for having the will and interest to complete this tremendous task.

Richard Lee University of Missouri-Columbia

Agri Marketing, Vol. 19, No. 1, January, 1981.

This issue is loaded with suggestions for anyone who works with the agricuitural press or broadcast media. The suggestions are aimed primarily at commercial companies and the public relations firms that represent them. However, many of the ideas are also applicable to persons in university and government information offices.

There is continuing debate about magazine use of stories written by public relations firms on behalf of a client. The magazine editors' stand might be summed up as: Call us before submitting; read our magazines so you'll know what we can use; make it a useful, objective story for our readers. Editors are concerned that they may get only one side of the story-the positive side.

Editors said they liked getting a list of contacts from whom they can get their own story.

Some alternatives to the conventional type of press conference are discussed.

"One of the great ones is when they come to your office and do their dog and pony show in two or three hours, they are gone, and you've covered what last time took you three days," an editor sald.

This idea could be used effectively by more agricultural information staffs. Information specialists could line up media visits for some of their top scientists when they are out on other trips. Or, special media tours could be arranged.

A telephone conference hookup was described as another alternative to a press conference. One PR firm reported a hookup which included a moderator in New York, company officials in Philadelphia, the agency staff in St. Joseph, and editors across the nation.

Page 56 is devoted to basic check lists on sending out news releases, and holding news conferences and special meetings. While the tips are very basic, they are a good reminder of the attention that should be 
Journal of Applied Communications, Vol. 64, Iss. 2[1981], Art. 6

paid to details.

Agri Marketing also publishes an annual marketing services guide which is an excellent directory of agricultural companies, advertising and public relations agencies, print and broadcast media, and agricultural associations.

Deimar Hatesohi University of Missouri-Columbia

"Public Service Utilization by Texas Radio Stations." W. Bryant Boutwell. Journallsm Quarterly, Winter, 1980.

Boutwell queried 176 Texas public service directors concerning rejection of public service announcements (PSAs). Three factors emerged as criteria for acceptance or rejection: The degree of community relevance, production quality and (profit/non-profit) status of the organization sending the PSAs. (Respondents insisted that organizations willing to buy print or television time would not likely recelve free radio time for PSAs.)

Respondents preferred scripts only (19\%), tape only $(12 \%)$, preferred script but would use tape $(15 \%)$, preferred tape but would use script $(35 \%)$, and $19 \%)$ had no preference. Respondents were able to indicate more than one "preferred" format. Nearly 43 percent preferred 10-second spots; 78 percent, 30-second; and 36 percent, 60-second PSAs.

More than one in four used all or almost all the PSAs they received, 19 percent used only one fourth of them, 28 percent used about half, and 27 percent used roughly three out of four.

Time and money might be better spent using PSA campaigns sensitive to these station needs, characteristics and local values.

Randy Weckman University of Kentucky

"Enjoyment and Information Gain in Science Articles." Aian Hunsaker. Journallsm Quarterly, Autumn, 1979.

Can a science writer convert dull journal reading into enjoyable magazine or newspaper articles-without 
sacrificing authenticity? Ask Alan Hunsaker. To test this, he took a formal journal article as a source and drafted two other versions-one modeled after the typical Science News article and the other following the typical Science article. Science News is more popularized than Science.) Hunsaker used 18 contextual measures in conforming with the styles of Science and of Science News.

Hunsaker presented his three versions to a panel of 71 community college students. Each student reviewed only one version and only saw that one version.

Results indicated that reader enjoyment increased as the article became more popular, but that enjoyment did not decrease information gain. Hunsaker used an effective scale and a cognitive scale to test for differences.

Randy Weckman University of Kentucky

Sinofsky, Esther R. and Frederick G. Knirk. "Choose the Right Color for Your Learning Style." Instructional Innovator. Vol. 26, No. 3, March, 1981, pp. 17-19.

Feeling "blue" today? Or "green" with envy? We match people's moods with colors quite often, and probably don't think too much about it. Have you thought about the color of the room where you are, as you're reading this? If not, maybe you should, say Sinofsky and Knirk in a recent article. In it they highlight the influences of color on our attitudes, our behaviors, even our abilities to learn.

If you're going to be designing or painting an extension learning center, or a $4-\mathrm{H}$ activity room, consider the color scheme. Need to schedule a meeting room for agriculture specialists to get together and generate ideas? The color of the meeting room you choose might be more important than you think, according to these authors. A variety of research studies cited in this article suggest that environmental colors have direct influences on how people respond to various tasks. This has direct implications for communicators. We need to be aware of these environmental psychological factors affecting our audiences. Some colors promote thinking. Red has been shown to increase 
body tension, for example. Colors that are bright, light and warm seem to stimulate activity and action. Still others-the blues and greens-are "cool colors'" that tend to encourage withdrawal and introspection.

These authors cite other findings which indicate that color may even affect attention span. It may be important, then, to consider your audience color preference in designing instructional facilities, choosing paper that materials are printed on, and selecting background colors for slides.

The article presents a summary of recent research concerning different color preferences by age, gradelevel, and by culture. For example, children in the 2-4 age group choose red as their favorite color more than any other. Those in the 3-6 year age range like oranges, pinks and reds the best. As we get older, our average color preference gradually shifts form the "warm" colors at the red end of the spectrum, to the blue or "cool" colors. And, if you're aiming a message at those in the 65 to 89 age group, you need to be aware that they don't prefer the restful pastel colors. They do like bright primary colors.

Different cultures have a variety of color preferences, according to research studies. So, if you're working in international programming or communication, you might find out the color preferences of the particular peoples you are working with.

Some studies cited in the article show that colors can be used to change a person's perception of time passage, of spaclousness in a room, even total room size.

The article summarizes these findings nicely, and gives tips about using and choosing color in learning spaces, on signs and in rooms designated for particular functions.

The concrete examples and organization of the research findings in this article make it both intriguing and practical. If you take the authors' advice, you'll read and study this article in a blue room, then move to a red one to start generating Ideas on how you'll use the information. 
Lee et al.: Farm Broadcasting--The First Sixty Y ears; A gri M arketing; "Public Instant Speaking Course. B. Lauren Lillis, The Interstate Printers \& Publishers, Inc., Danville, Illinois, 1981. $\$ 1.50$.

"Instant Speaking Course" is a delightful, highly useful book for the person who has to give an occasional speech and would like to make it a good one. In 25 easy-to-read, nicely illustrated pages, it gives tips on speaking effectiveness, describes a breathing exercise that adds more power to your speaking voice, and tells how to build confidence.

Specifically, the author reminds us to avoid "word whiskers" (superfluous sounds and words like "uh," "you know," etc.). He also tells us how to add emphasis and expression, how to deal with difficult speaking places (and difficult audiences), and how to relate to audiences, public or private speaking situations.

"Instant Speaking Course"' was written by B. Loren Lillis, broadcast journalist, WGR-TV, Buffalo, New York.

Joe Marks University of Missouri-Columbla 